\title{
THE RIGHT TO BE FORGOTTEN IN POST-GOOGLE SPAIN CASE LAW: AN EXAMPLE OF LEGAL INTERPRETIVISM IN ACTION?
}

\begin{abstract}
Recent judgments by the European Court of Justice and the Federal Constitutional Court of Germany have helped to clarify the scope of the Right to be forgotten. This article addresses these judgments and highlights the path the Right to be forgotten has taken since the Google Spain case. The author asserts that the Right to be forgotten is a good example of legal interpretivism in action, as the judgments have developed and transformed the right in ways that Google Spain and the General Data Protection Regulation could not have foreseen. The element of time gained prominence in the role of balancing and is highlighted as an example of policy shaping conducted by the Courts. The article concludes with an analysis of blockchain as a next potential battleground for the Right to be forgotten and provides an outlook on how the Courts might handle issues related to this, in line with the legal interpretivist school.
\end{abstract}

\section{Keywords}

Right to be Forgotten - ECJ - German Constitutional Court - Legal Interpretivism Blockchain

\footnotetext{
* PhD Candidate, Tallinn University, Estonia; carsten.wulff@hotmail.com

** Funding for this publication was provided by the Kristjan Jaak Scholarship.
} 


\section{INTRODUCTION}

Since the landmark Google Spain judgment of the ECJ, ${ }^{1}$ the concept of the Right to be forgotten (Rtbf) as a distinct right derived from the right to privacy and protection of personal data, ${ }^{2}$ has gained considerable momentum. The right, which before Google Spain had been only briefly discussed by the $\mathrm{EU}^{3}$ and academics, ${ }^{4}$ is considered to be an extension of the Right to erasure to allow for the deletion of personal online data, adding a right for the data subject to object to processing if there are no overriding legitimate grounds for processing. ${ }^{5}$ Most post-GDPR litigation

${ }^{1}$ Case C-131/12, Google Spain SL and Google Inc. v Agencia Española de Protección de Datos (AEPD) and Mario Costeja González, available at: http://curia.europa.eu/juris/ document/ document.jsf?docid=152065\&doclang=EN (last accessed 13.12.2019).

2 As listed in the Charter of Fundamental Rights of the European Union C-326/02, Articles 7 (Respect for Private and Family Life) and 8 (Protection of Personal Data).

${ }^{3}$ COM (2010) 609 Final, "Communication from the Commission to the European Parliament, the Council, the Economic and Social Committee and the Committee of the Regions: A comprehensive approach on personal data protection in the European Union.", Brussels 4.11.2010 outlines the need for better enforcement of privacy rights online. V. Reding, "Privacy Matters - Why the EU needs new personal data protection rules", Speech/10/700 - The European Commissioner for Information Society and Media emphasized the importance of implementing the Rtbf.

${ }^{4}$ V. Mayer-Schönberger, Delete: The Virtue of Forgetting in the Digital Age, Princeton University Press, 2009, passim and his keynote speech at the 2008 re:publica conference in Berlin, Germany, on data protection for web 2.0 and the Right to be forgotten.

${ }^{5}$ General Data Protection Regulation 2016/679/EU http:/ / eur-lex.europa.eu/ legal-content/EN/TXT/PDF/?uri=CELEX:32016R0679\&from=EN (accessed 14.12.2019) Art. 17, "The data subject shall have the right to obtain from the controller the erasure of personal data concerning him or her without undue delay and the controller shall have the obligation to erase personal data without undue delay where one of the following grounds applies ... (c) the data subject objects to the processing pursuant to Article 21(1) and there are no overriding legitimate grounds for the processing, or the data subject objects to the processing pursuant to Article 21(2)".

The right to object, further outlined in Art.21 provides for exceptions, "if the processing is carried out to for the performance of a task carried out in the public interest or in the exercise of official authority vested in the controller (Art. 6 [e]) or, "processing is necessary for the purposes of the legitimate interests pursued by the controller or by a third party, except where such interests are overridden by the interests or fundamental rights and freedoms of the data subject which require protection of personal data" (Art. 6 [f]). 
has focused on the delisting of search results by search engines. The Google Spain judgment deduced and the GDPR granted a right to have these removed from an Internet search engine on the grounds that, "the data appear[s] to be inadequate, irrelevant or no longer relevant or excessive in the light of the time that had elapsed." ${ }^{16}$ The wording of the GDPR, which entered into force in May 2018, included the Rtbf in article 17 , but did not address important factors for a successful enforcement of this right, such as whether search results must also be altered for nonEuropean domains and whether websites of media outlets must also delete articles after a certain period of time has passed.

Regarding the ontological scope of the Rtbf, two schools of thought have emerged as the leading ones, the Rtbf as a sort of right to oblivion, and the Rtbf as an extension of the right to erasure, which also could be considered a right to suppression ${ }^{7}$ or right to removal. ${ }^{8}$ The former sees the Rtbf as a chance for an individual to be relieved of his past and be able to start with a clean bill. ${ }^{9}$ Human memory historically has been biased towards forgetting. As time lapses, memories become less clear as the mind becomes less able to retrieve all aspects of the memory. ${ }^{10}$ The emergence of cheap online storage options has opened the opportunity for these memories to be saved externally and remain easily accessible for a long period of time. Additionally, they are not stored in context, which may lead to the memories being reviewed without the necessary context in the future. In order to restore such a right to oblivion, Mayer-

${ }^{6}$ Case C-131/12, Google Spain, supra note 1, para. 92.

7 C. Kuner, "The Court of Justice of the EU Judgment on Data Protection and Internet Search Engines", LSE Law, Society and Economy Working Papers 3/2015, p. 7, available at: https:/ / papers.ssrn.com/sol3/papers.cfm?abstract_id=2496060 (last accessed 14.02.2020)

8 S. Uncular, "The right to removal in the time of post-Google Spain: myth or reality under general data protection regulation?", International Review of Law, Computers $\mathcal{E}$ Technology, 2019, Vol. 33 (3), p. 310.

9 U. Pagallo, M. Durante, "Legal Memories and the Right to be Forgotten", in L. Floridi (eds.), Protection of Information and the Right to Privacy - A New Equilibrium? 2014, Springer Verlag, p. 19.

${ }^{10}$ In this context, Schachter speaks of the seven sins of memory - transience, absentmindedness, blocking, misattribution, suggestibility, bias and persistence, in: D. Schachter, The Seven Sins of Memory: How the Mind Forgets and Remembers, 2001, Houghton Mifflin, passim. 
Schönberger has proposed six solutions: digital abstinence, information privacy rights, digital privacy rights infrastructure, cognitive adjustment, information ecology, and perfect contextualization. ${ }^{11}$ The objective of all of these solutions is to reclaim the possibility of forgetting and to give individuals back control of their data. ${ }^{12}$

There is also the ongoing philosophical debate as to the role of oblivion in social interaction and the increasing amount of data and information that shape individual identity. The Rtbf in this context can be seen as an expression of autonomy with which every individual should be able to present and describe him or herself on three levels: (1) The construction of personal identity through revision of the past, (2) The relation between individual and collective memories, (3) The different forms of oblivion vis-à-vis the idea of forgiveness. ${ }^{13}$

Through erasing traces of the past, individuals can establish a new identity within a new social group. However, there is the risk of maximum conformity to such a group. It is possible to live without remembering, but impossible to live without forgetting. Being able to trace the past, enables society to forgive what happened in the past. ${ }^{14}$

The second school of thought sees the term, "Right to be forgotten" as an unfortunate misunderstanding. Google Spain never established a 'new' right, it merely clarified the scope of the right to erasure. Advocates of this school of thought believe that the implementation of an actual Rtbf would pose a serious threat to freedom of expression, ${ }^{15}$ and that its downsides would outweigh the benefits. ${ }^{16}$ Furthermore, the ECJ failed

${ }^{11}$ Mayer-Schönberger, supra note 4, pp. 132-168.

12 Stated as an objective in the speech of: V. Reding, "Privacy Matters - Why the EU needs new personal data protection rules", Speech/10/700.

${ }_{13}$ Pagallo, Durante, supra note 9, p. 21.

${ }^{14}$ Ibid., p. 27, initial concept of "fair memory" and "difficult forgiveness" by V. Jankélévitch, Forgiveness, 2005, The University of Chicago Press, passim.

15 J. Rosen, "The Right to Be Forgotten", Stanford Law Review, Symposium Issue, 2012, available at: http://www.stanfordlawreview.org/online/privacy-paradox/right-to-beforgotten [last accessed 14.02.2020].

${ }^{16}$ E. Adams Shoor, "Narrowing the Right to Be Forgotten: Why the European Union Needs to Amend the Proposed Data Protection Regulation", Brooklyn Journal of International Law, 2014, Vol 39, pp. 487-521. 
to take into account the case law of the ECtHR to provide a more solid basis for the Rtbf. ${ }^{17}$

Following an assessment of the recent judgments by the ECJ and Federal Constitutional Court of Germany (BVerfG) which address these issues, the article will review these judgments in the light of the legal interpretivist school of thought, which asserts that the Courts have the power to shape the law through their judgments. The law is seen as a chain, an unravelling novel written by judges and constantly updated through more recent judgments. ${ }^{18}$ Judgments reflect the current political landscape while weighing the arguments against the principles of justice and fairness to produce an outcome which benefits the majority of society. ${ }^{19}$ The element of time is highlighted as an element introduced in the balancing of competing rights which was not directly foreseen by the legislators. In the third section, the article will briefly provide arguments why blockchain might be the next field which the ECJ will tackle in order to develop the scope of the Rtbf. As the analysis will also show, as a consequence of the incomplete nature of the Rtbf in the GDPR, the Courts are developing the scope of the Rtbf to become a compromise between a mere extension of the right to erasure and a full right to oblivion.

\section{RECENT JUDGMENTS}

\section{Spiegel Online V. Volker Beck}

Spiegel Online dealt with a publication by a former member of the German Parliament, Beck, re-emerging 25 years after its initial publication. The re-emergence led to significant media attention as it dealt with "criminal policy relating to sexual offenses committed with minors." ${ }^{20}$ Beck claimed

17 Uncular, supra note 8, p. 317.

${ }^{18}$ In line of Dworkin's theory of legal interpretivism, laid forth in R. Dworkin, Law's Empire, 1986, Belknap Press, the chain of law is highlighted in Chapter 7, pp. 228-238.

${ }_{19}$ Ibid., Chapter 8, the question of justice pp. 285-288.

${ }^{20}$ Case C-516/17 Volker Becker v Spiegel Online GmbH, EU:C:2019:625 (29.7.2019) at para. 10 . 
that at the time of the publication, the publisher made choices, which he objected to, which changed the context of certain passages of the manuscript. Beck made available the original manuscript to publishers and published the manuscript on his own website, stating that he distances himself from the content. ${ }^{21}$ Beck brought an action against the German news site, "Spiegel Online" contesting the making available of a link to the original manuscript without Beck's statements, in an article published on the website, as a violation of Directive 2001/29 (Copyright Directive). ${ }^{22}$ As the case also touches on issues relating to the Charter of Fundamental Rights, the mid-tier Court referred the case to Luxembourg. ${ }^{23}$

The Court assessed whether the way the Copyright Directive was implemented into national law ensured an adequate level of protection of the Charter of Fundamental Rights. The Directive allows exceptions for the, "use of works or other subject matter in connection with the reporting of current events, to the extent justified by the informatory purpose and as long as the source, including the author's name, is indicated, unless this turns out to be impossible", and, "quotations for purposes such as criticism or review, provided that they relate to a work or other subject matter which has already been lawfully made available to the public, that, unless this turns out to be impossible, the source, including the author's name, is indicated, and that their use is in accordance with fair practice, and to the extent required by the specific purpose". ${ }^{24}$ The Court further qualified this assessment through a review of the legislative drafts leading up to the final Directive. ${ }^{25}$

${ }^{21}$ Ibid., para 11.

${ }^{22}$ Directive 2001/29/EC of the European Parliament and of the Council of 22 May 2001 on the harmonization of certain aspects of copyright and related rights in the information society OJ L 167, 22.6.2001.

23 Ibid., para 15.

${ }^{24}$ Paras 26 and 28, in such cases, 'to the extent justified by the informatory purpose' and 'in accordance with fair practice, and to the extent required by the specific purpose' respectively, that, in the transposition of that provision and its application under national law, the Member States enjoy significant discretion allowing them to strike a balance between the relevant interests.

${ }^{25}$ Para. 29, specifically COM 97 (628) is mentioned, which states that the limitations under Article 5 are specifically not dealt with in detail and left for the Member States to define in their final use. 
The Court deduced that freedom of information and freedom of the press cannot justify a derogation of the author's exclusive rights of reproduction and communication and of communication to the public beyond the exceptions or limitations provided in Article 5 (3). ${ }^{26}$ Concerning cases that fall within those exceptions, such as the case at hand, it is of relevance that the quoted material be, "in connection with the reporting of current events." ${ }^{27}$ In general, when reporting a current event, it is important for the information to be diffused rapidly, which makes it difficult to obtain the author's prior consent. ${ }^{28}$ When quoting an unauthorized text, a close link must exist between the quoted text and the reflections made with it. ${ }^{29}$ Only as much should be quoted as is necessary to convey the message. A specific work which was previously lawfully made available to the public remains lawfully available to the public. ${ }^{30}$

\section{GOOGLE V. CNIL}

This case dealt with the extraterritorial scope of the GDPR. The French data protection authority (CNIL) imposed a fine of $€ 100000$ on Google for failing to delist search results in non-European domains. The CNIL argued that in order to assure an adequate protection of data subjects' rights under the 1995 Data Protection Directive (the Court reviewed the case in the light of the GDPR), Google must delist search results under all of its domains once a delisting request is approved. It asked the ECJ to rule on whether Google must delist search results, [1] across all of its domains, [2] only under the EU Member States' domains and [3] whether

${ }^{26}$ Derogations are permitted, (c) "in cases where such use is not expressly reserved, and as long as the source, including the author's name, is indicated, or use of works or other subject matter in connection with the reporting of current events" and (d) "quotations for purposes such as criticism or review, provided that they relate to a work or other subject matter which has already been lawfully made available to the public".

27 Ibid., para. 64.

${ }^{28}$ Ibid., para. 71.

${ }^{29}$ Ibid., para. 79.

30 Ibid., para. 95. 
Google must enforce 'geo-blocking' based on the location of the search request. ${ }^{31}$

Although the Court affirms that the aim of the GDPR is to, "guarantee a high level of protection of personal data throughout the European Union" 32 and asserts, "that a de-referencing carried out on all the versions of a search engine would meet that objective in full" 33 , the Court also highlights, "that numerous third States do not recognize the right to dereferencing or have a different approach to that right." 34

Following considerations regarding the scope of the GDPR and the intentions of the legislators ${ }^{35}$, the Court concludes that Google is under no obligation to delete its search results in non-European domains. ${ }^{36}$ Regarding the effectiveness of Google's "geo-blocking" measures, this is up to the French Court to decide. The judgment follows the opinion of the advocate general. Advocate general Szpunar in his opinion especially highlighted the importance of balancing privacy rights with freedom of information. ${ }^{37}$

The judgment in Beck established that a specific work which was initially made available to the public lawfully, remains lawfully available to the public. The judgment in CNIL clarified that the scope of the Rtbf is limited to European domains.

${ }^{31}$ Case C-507/17, Google LLC v Commission nationale de l'informatique et des libertés (CNIL), ECLI:EU:C:2019:772, summarized from para. 49.

${ }^{32}$ Ibid., para. 54.

33 Ibid., para. 55.

34 Ibid., para. 59.

${ }^{35}$ In para. 62, the Court finds that, "it is in no way apparent from the wording of Article 12(b) and subparagraph (a) of the first paragraph of Article 14 of Directive 95/46 or Article 17 of Regulation 2016/679 that the EU legislature would, for the purposes of ensuring that the objective referred to in paragraph 54 above is met, have chosen to confer a scope on the rights enshrined in those provisions which would go beyond the territory of the Member States".

36 Ibid., para. 64.

37 Opinion of AG Szpunar, Case C-507/17, Google LLC v Commission nationale de l'informatique et des libertés (CNIL), ECLI:EU:C:2019:15. 


\section{Federal Constitutional Court of Germany}

Following in the footsteps of its "Solange" doctrine ${ }^{38}$, in cases 1 BvR 16/13 (Rtbf 1) and 1 BvR 276/17 (Rtbf 2), the BVerfG ruled on the compatibility of the Rtbf with the German Basic Law in November 2019.

In Rtbf 1, the applicant requested that the website of a German periodical remove the link to an article about crimes he committed in the past. The applicant was punished for the crime, served his sentence and was released in 2002. The applicant argued that the article being locatable through a search of his name constitutes an infringement of his right to personality. ${ }^{39}$ The lower tier Courts granted his request, the appellate Court (Bundesgerichtshof) overruled and ruled in favour of the publisher. The data protection officers of multiple German States in a joint declaration, supported the appeal to the highest German Court as the case raises serious questions about the enforceability of a Rtbf against the media. Website owners by means of a robots exclusion standard can make certain parts of their websites unavailable to search engine providers.$^{40}$ Google Germany in its declaration argued that if the content itself is legally available, there should be no restrictions on its being found by search engines. ${ }^{41}$ The German association of Internet economy argued that the same standards should apply for online and offline publications. ${ }^{42}$

${ }^{38}$ In Re Wünsche Handelsgesellschaft (22 October 1986) BVerfGE 73, 339, commonly

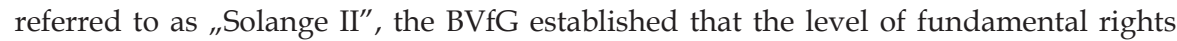
protection on the European level was comparable to that of the German Basic Law (Grundgesetz). Therefore, it will not conduct a review of the compatibility of European laws with the German Basic Law as long as the scope of protection granted by European law is comparable to that of the German Basic Law.

39 Bundesverfassungsgericht, 1 BvR 16/13 at para. 4. The right to personality (Recht of freie Entfaltung der Persönlichkeit) is listed in Art. 2 of the German Basic Law and includes the right to informational self-determination, deduced by the Court in $1 \mathrm{BvR}$ 209, 269, 362, 420, 440, 484/83.
40 Ibid., para. 19.
41 Ibid., para. 29.
42 Ibid., para. 33. 
As the case dealt with potential exceptions to the application of the Rtbf under the journalistic purposes clause in Art. 85 GDPR, ${ }^{43}$ the BVerfG deduced that the case allows for a margin of appreciation of member states and therefore it has the authority to deliver a judgment. ${ }^{44}$ The Court found that cases may exist where the scope of protection granted by European human rights instruments may go beyond the rights protected in the German Basic Law. In such cases, the Court accepts the higher standard.$^{45}$ In its analysis, the Court also assessed the judgment in M.L. and W.W. v. Germany, in which the ECtHR, while denying the existence of an enforceable Rtbf, did highlight the importance of convicted felons to not be confronted with their past anymore after a certain period of time has passed. ${ }^{46}$

Concerning the specific case, the Court established that the right to informational self-determination can include that an individual can expect to not be held accountable for certain acts that happened in the past. Being so accountable could hinder the affected individual from pursuing an active role in society ${ }^{47}$ The press is under no obligation to review its online archive, and it always will need to be the individual

${ }^{43}$ Art. 85 GDPR, "1. Member States shall by law reconcile the right to the protection of personal data pursuant to this Regulation with the right to freedom of expression and information, including processing for journalistic purposes and the purposes of academic, artistic or literary expression. 2. For processing carried out for journalistic purposes or the purpose of academic artistic or literary expression, Member States shall provide for exemptions or derogations from Chapter II (principles), Chapter III (rights of the data subject), Chapter IV (controller and processor), Chapter V (transfer of personal data to third countries or international organizations), Chapter VI (independent supervisory authorities), Chapter VII (cooperation and consistency) and Chapter IX (specific data processing situations) if they are necessary to reconcile the right to the protection of personal data with the freedom of expression and information."

${ }^{44}$ Bundesverfassungsgericht, 1 BvR 16/13 at para. 39.

45 Ibid., para. 64.

${ }^{46}$ Ibid., at para 106. In M.L. and W.W. $v$ Germany, the Court found that publishers do not need to anonymize personal data in their online archives. Similar to the Google Spain case, for the applicants, the media attention from the proceedings has likely made them more well-known to the public opposed to if they would not have commenced proceedings - European Court of Human Rights, Appl. Nos 60798/10 and 65599/10, Judgment of 28.06.2018.

47 Ibid., para. 108. 
who needs to first ask for deletion. ${ }^{48}$ In principle, it is reasonable to expect the media outlets to be obligated to invest in technical measures to avoid a listing of certain results - through uploading articles to the internet, the media outlets place themselves under an obligation to also control the means of access. ${ }^{49}$

The lower tier court failed to consider how easy it was to find the article about the individual through a simple Google search. Considering that the applicant had already served his sentence and had to integrate into a new community, the negative stigmatization could hinder him from pursuing an active role in society. ${ }^{50}$ As in contrast to M.L. and W.W. v. Germany, the individual also did not seek public attention, the Court overruled the decision of the lower tier Court, with the recommendation to implement a solution which blocked access to the article using only the individual's name as the search parameter. ${ }^{51}$

In Rtbf 2, the BVerfG dealt with a television documentary which remained available online after its initial airing in 2010. In the documentary, which dealt with questionable practices of employers in order to fire employees, the individual was interviewed, and the name was captioned in. ${ }^{52}$ In 2016, a Google search of the plaintiff's name produced a link to the video as the first result. The plaintiff asked Google to remove the search result, but Google refused. The plaintiff then sought an injunction from the lower tier Court to force Google to remove the result, which it granted. The lower tier Court concluded that enough time had passed and the plaintiff's right to informational self-determination should be weighted higher than the freedom of the press to make the link available to Google. The Court qualified this assessment with a six year 'good grace period' (Wohlverhaltensperiode) as known in German insolvency law. ${ }^{53}$ The freedom of enterprise of Google, also does not tip the scale in

${ }^{48}$ Ibid., para. 117.
${ }^{49}$ Ibid., para. 139.
${ }^{50}$ Ibid., para. $147-148$.
${ }_{51}$ For a more comprehensive analysis, see M. Sachs, Verfassungsprozessrecht: Grundrechtskontrolle des BVferfG bei Durchführung von Unionsrecht, JuS 3/2020, p. 282-284.

${ }^{52}$ Bundesverfassungsgericht, 1 BvR 276/16 at para 2.

${ }^{53}$ Ibid., paras 5-6. 
favour of retaining the link. Furthermore, the video itself would cause the "average internet user" to obtain a negative picture of the plaintiff's personality. ${ }^{54}$

Google appealed and the mid-tier Court ruled in its favour. The video does not affect the private sphere, but only the social sphere. Furthermore, the plaintiff agreed to the interview, which implied consent to the documentary being aired and potentially leading to a degree of public attention. Even six years later, the public interest in this topic is high enough to warrant the documentary's continued availability as a function of the press. Finally, it quashed the lower Court's argument for using a six year 'good grace period' as a time-limit for deciding when the personality rights override the freedom of information. ${ }^{55}$ The case reached the BVerfG, where the plaintiff emphasized that the public interest in the dispute which only involved the two parties and lay six years in the past was low and did not outweigh personality rights. Furthermore, the plaintiff highlighted that justice would be served if the video could only be found through adding additional terms to the search using her name, such as 'tricks' and 'termination'. ${ }^{56}$

As this case does not touch on media privilege exemptions, the Charter of Fundamental Rights is applicable, as the scenario is fully covered by Union law. ${ }^{57}$ Only the Charter can be applicable as the entire aim of a regulation is to harmonize the law across the entire European Union. Applying national norms would run contrary to this cause. The Court also reached the conclusion that the ECHR is not applicable as it does not provide the same level of protection as the Charter of Fundamental Rights. Nonetheless, due to different judicial traditions, even with the use of the Charter, national Courts may reach different conclusions. ${ }^{58}$ The Court deduced that Constitutional complaints can also be launched for issues solely touching on Union law as this is to be interpreted as an

54 Ibid., para. 9.

55 Ibid., paras 10-11.

${ }^{56}$ Ibid., para. 16.

57 Ibid., at para. 36, for a comprehensive analysis, see M. Sachs, "Verfassungspro zessrecht:Verfassungsbeschwerde und Unionsgrundrechte", JuS 3/2020, pp. 284-286.

58 Ibid., paras 44-45. 
extension of the national legal order. This is an expansion of the Solange II doctrine. ${ }^{59}$

Google can rely on protection for its economic freedoms under Article 16 of the Charter of Fundamental Rights, but cannot rely on freedom of expression of the press. ${ }^{60}$ Article 11 however can apply for the original source of the link, as a hindering of displaying its result can equate to a violation of its freedom of expression. ${ }^{61}$ The Court deduces that the outcome might be different depending on whether the link should be taken down from the search engine or from its original source. Furthermore, although the mid-tier Court used the German Basic Law instead of the Charter in its assessment, the BVerfG found that the midtier Court gave consideration to the same issues that the Charter would have touched and hence the Constitutional Court will not evaluate the outcome of the balancing reached by the mid-tier Court. ${ }^{62}$

The mid-tier Court rightly deduced that the outcome of the balancing might differ if the plaintiff pursued an action against the website itself or the search engine and rightly deemed the claim against the search engine to be admissible despite no action having previously been taken against the website. The conclusion that the video infringed only the plaintiff's social sphere was incorrect - although conducted in her work environment, it could lead to undue prejudice about her persona which could also be reflected in her private life. ${ }^{63}$ The Court rightly addressed that the plaintiff agreed to the interview without being pressured to do so and there were no indications that the interviewer deceived her about the nature of the interview. The Court also took into account the aspect of time and that as the time passes, the personality rights increase whereas the rights of the search engine to pursue its economic interest through

59 Ibid., para. 67, Sachs highlights that the Court confirmed that the protection of fundamental rights through the review of Constitutional complaints remains one of the Court's primary tasks, and therefore it must have jurisdiction to review domestic cases in the light of Art. 51 of the Charter of Fundamental Rights where the facts of the case are fully covered by EU law.

${ }^{60}$ Ibid., paras. 102 and 105, in line with the reasoning of the ECJ in Case C-131/12, Google Spain.
61 Ibid., para. 108.
${ }^{62}$ Ibid., paras 111 and 115.
${ }^{63}$ Ibid., para. 124 and 128. 
retaining the results decrease. The element of fulfilment of the purpose of publication is not an adequate standard for balancing. In this case, as the plaintiff herself agreed to the broadcast of the interview and there is still a public interest in the topic itself, seven years cannot be viewed as an excessive amount of time. ${ }^{64}$

\section{LEGAL INTERPRETIVISM}

\section{KeY CONCEPTS}

Legal interpretivism as laid forth by Dworkin in his book "Law's Empire" is a theoretical framework which enables one to view law as socially constructed, containing both elements of natural and positive law, which pertain only to the legal sphere. ${ }^{65}$ His theory views law as an interpretive process, which contains elements of both positive and natural law, but at the same time is different from both. Law can only be authority if it was drafted in a proper legislative process and reflects legal principles established within the legal tradition. His perception of law distances itself from natural law, as law and morality do not have to go hand in hand. What matters is that the law reflects values that have been established and developed within the legal community. ${ }^{66}$

In this perception of the law, judges play a pivotal role in developing the law through their judgments. When confronted with the task of balancing competing rights, judges need to balance arguments of justice and fairness. A judgment can provide justice, but not adhere to principles of fairness. As an example, he lists the landmark case of Brown v. Board of Education which dealt with the issue of segregation at American schools. ${ }^{67}$ Using the perfect judge, 'Hercules' ${ }^{68}$, a just outcome which in any case

${ }^{64}$ Ibid., paras 132 and 135.

${ }^{65}$ N. Stavropoulos, in E.N. Zalta (ed.) Legal Interpretivism, The Stanford Encyclopedia of Philosophy (Summer 2014 Edition), http:/ / plato.stanford.edu/archives/sum2014/entries/ law-interpretivist (last accessed 12.12.2019).

${ }^{66}$ Dworkin, supra note 18, pp. 90-96.

${ }^{67}$ Brown v. Board of Education of Topeka, 347 U.S. 483 (1954).

${ }^{68}$ Hercules, introduced by Dworkin in Law's Empire is a perfect judge who always 
sees all individuals as equal under the law, would terminate the policy. A fair result however considers the impacts of terminating the policy for third parties, in this case the education system as a whole, which would be put in a state of chaos if the policy of school segregation was instantly terminated. ${ }^{69}$

Judges are engaged in creating a chain of $l a w^{70}$ through their judgments. He does not believe in a strict interpretation of binding precedent. As law is interpretive, judges must respect the principles derived from former judgments, but should not shy away from distinguishing the facts of the case at hand to alter the chain of law. Law is hence constructed by the lawyers and can change over the years. The outcome in Brown v. Board of Education as an example was highly controversial when delivered; however it has been 'accepted' by the chain of law in subsequent judgments and hence has become rooted in the law.

The question central to interpretivism is what the "heart of the law" is. ${ }^{71}$ The values central to the heart of the law are not propositions which people find to be valuable, but rather those which people are obliged to accept. ${ }^{72}$ The heart of the law therefore is about finding the key objectives society wants to accomplish, and which obligations individuals need to accept in order to accomplish this objective. ${ }^{73}$

\section{Application on the Right to be Forgotten}

In order to test the Rtbf in the light of legal interpretivism, arguments have to be found in the judgments that the Courts have not just been

knows all the facts of the case, the relevant laws and can interpret competing rights in the light of the tradition of legal practices specific to the country.

${ }_{69}$ Dworkin, supra note 18, pp. 387-392.

${ }^{70}$ Ibid., pp. 228-238.

${ }^{71}$ R. Dworkin, Justice in Robes, 2006, Harvard University Press, p. 141.

72 B. Cali, "On Interpretivism and International Law", The European Journal of International Law, 2009, Vol. 20 (3), p. 808.

${ }^{73}$ Dworkin highlights that such values, 1 . Have to show that the values are distinct to law. 2. The values must be widely accepted as 'real' values in the practice of law. 3. They should provide guidance on which propositions about what the law is on a particular 
delivering technical judgments, but rather that through the judgments, the Courts have developed the Rtbf. It is widely accepted that the Google Spain case was decisive in setting the Rtbf apart from the right to erasure. ${ }^{74}$ The Google Spain case took into account an issue which still affects the legislator today - the law is struggling to keep up with technological developments. The 1995 Directive did not foresee the rapid development of the internet and the emergence of search engines which do not forget anything. ${ }^{75}$ The judgment, although controversial does not go against the nature of what the legislators intended with the 1995 Directive - rather it takes into account what the legislators intended ${ }^{76}$ and existing caselaw to deduce a legal right from the Directive which was not foreseen yet in 1995. The judgments discussed above serve as evidence that both domestic Courts and the ECJ have accepted the principles of Google Spain and are continuing to develop the scope of the Rtbf.

In Rtbf 1 , the Court highlighted the importance of balancing competing rights in such a way that it reflects the "importance of society" and the "social importance" of the arguments. ${ }^{77}$ This is in line with the argument that Courts have to take into account aspects of justice and fairness, which do not always go hand in hand. ${ }^{78}$ Many of the arguments of the Court reflect the importance of interpreting the case in the light of concepts of justice and fairness. In Rtbf 2, the German Constitutional Court took upon itself the competence to apply the Charter of Fundamental Rights in

issue are true. 4. They have to be comprehensive enough to justify sources of law and reasons to follow the law (Dworkin, R., (1996) at p. 169). Emphasis on point 4 added by B. Cali - Ibid., p. 809.

${ }^{74}$ For example see S. Shanin, "Right to Be Forgotten: How National Identity, Political Orientation, and Capitalist Ideology Structured a Trans-Atlantic Debate on Information Access and Control," Journalism \& Mass Communication Quarterly, 2016, Vol. 93 (2).

75 J. Ausloos, "The 'Right to be Forgotten' - Worth remembering?", Computer Law $\mathcal{E}$ Security Review, 2012, Vol. 28.

${ }^{76}$ See for example COM (2003) 265 Final, "Report from the Commission: First report on the Implementation of the Data Protection Directive (95/46/EC), Brussels 15.5.2003 and COM (2007) 87 Final, "Communication from the Commission to the European Parliament and the Council: on the follow-up of the Work Programme for better implementation of the Data Protection Directive", Brussels, 7.3.2007.

77 Bundesverfassungsgericht, 1 BvR 16/13, para. 77.

78 Dworkin, supra note 18 , pp. 73-76. 
domestic cases, where the protection under the German Basic Law is not sufficient and the case solely deals with issues covered by community law.

With CNIL, the ECJ set clear boundaries regarding the enforceability of the Rtbf extraterritorially, reflecting a realistic assessment as to what extent the Rtbf can currently be enforced. The judgment in Beck provides guidance on the duration of lawful publications online and hence indirectly, together with CNIL, also helps to concretize the Rtbf in both substance and scope.

An important aspect is to establish whether there is growing consensus among legislators, the Courts, and the public to enforce the Rtbf. As Google statistics reflect, the amount of deletion requests varies drastically from State to State. As the report also shows, an increasing number of European citizens have become aware of the Rtbf and are willing to submit a delisting request. ${ }^{79}$ Social acceptance of the Rtbf may lead to a stricter enforcement of the right as it can show a common acceptance in society of the principles of the right.

According to Dworkin, Courts can shape the norm, although in civil law systems the chain of law is less hard without binding precedent. This is where legal interpretivism can find its limits in civil law systems. At the time of Google Spain, the EU was still under the influence of the Prism scandal..$^{80}$ The recent judgments in CNIL v France and the BVferG display a realistic assessment of the Courts regarding to what extent the Rtbf can currently be enforced and the judgment in CNIL displays less enthusiasm towards the Rtbf compared to the Google Spain judgment.

One key problem remaining for an effective enforcement of the Rtbf is its global implementation. Although public support for the Rtbf is present ${ }^{81}$, as case-law from the United States alone shows, the Rtbf is very

79 Transparency Report: Requests to delist content under European Privacy Law, available at https://transparencyreport.google.com/eu-privacy/overview?hl=en (last accessed 14.12.2019).

${ }^{80}$ PRISM is a program which the NSA uses to collect communications from various US companies. In 2013 information was leaked hinting that PRISM was used in a large scale to collect the communications of important European politicians and companies.

${ }^{81}$ P. Coffee, "Hey Google: 9 in 10 Americans Want the 'Right to Be Forgotten'”, 2015, available at: http:/ / www.adweek.com/digital/hey-google-9-in-10-americans-want-theright-to-be-forgotten/ (last accessed 13.12.2019). 
unlikely to be enforceable globally in the future. ${ }^{82} \mathrm{~A}$ "glocal" solution has been proposed, which would conduct geo-blocking and filtering of search results based on the IP address on which the search was conducted, ${ }^{83}$ and which the judgment in CNIL does not exclude as a possibility. ${ }^{84}$ However, users can avoid such geo-blocking through a simple altering of their IP-address, which multiple providers are offering in free-to-use applications.

The judgments discussed above leave open various "back-doors" to enable a wider interpretation of the Rtbf in the future while not compromising the previous judgments. As such, the 'chain of law' can still be altered to reflect the political landscape in the future.

\section{The Element of Time}

Another argument in favour of legal interpretivism can be found in the element of time, which the German cases address. Ultimately, the Courts have deduced and developed the element of time as a key factor in the balancing process. As the judgments acknowledge, privacy rights increase over time whereas the weight of economic interests of the data controller to retain the links decrease. Balancing must also take into account public interest in the matter and the nature of how the information was obtained. ${ }^{85}$ In the balancing process, the Courts also need to address other factors including whether the information deals with a public figure or contains information which might be important to the public. In this regard, the restrictions provided in the ECHR can

${ }^{82}$ To this end, see Riley v. California (discussed by A. Dimitrova, M. Brkan, "Balancing National Security and Data Protection: The Role of EU and US Policy-Makers and Courts before and after the NSA Affair", Journal of Common Market Studies, 2018, Vol. 56 (4). p. 754 and Melvin v. Reid 112 Cal.App. 285, 297 P. 91 (1931).

${ }^{83}$ Y. Padova, "Is the Right to be Forgotten a Regional, Universal or 'Glocal' Right?", International Data Privacy Law, 2019, Vol. 9 (1), pp. 26-27.

${ }^{84}$ Case C-507/17, Google LLC, supra note 31, para. 43. The final decision on what constitutes the most effective way to enforce the judgment is left to CNIL.

${ }^{85} \mathrm{Rtbf} 2$ established that consenting to the publication of an interview will be weighed in favour of retaining the information whereas Rtbf 1 ruled in favour of delisting in a case where the publication was not approved by the plaintiff. 
serve as guidance. ${ }^{86}$ Furthermore, the criteria developed in von Hannover may also help the Courts in the balancing task. ${ }^{87}$

The element of time is not considered in the GDPR. In the explanations, while outlining conditions under which data retention may be lawful, no advice is given on how the balancing of competing rights is to be conducted, nor is the element of time mentioned..$^{88}$ With the passage of time, the additional revenue obtained by the website for retaining the information online decreases, whereas the weight of the individual's privacy rights increase. ${ }^{89}$ This trend is not just visible in the recent judgments of the BVferG and the ECJ, but also in two Italian cases, Manni v. Camera di Commercio Lecce (ECJ) ${ }^{90}$ and Venditti v. Rai (Italian Supreme Court). ${ }^{91}$

In Manni, the plaintiff sought to have records deleted of a company he owned which had declared bankruptcy over ten years earlier, invoking his right to erasure under the 1995 Directive. ${ }^{92}$ The information

${ }^{86}$ Derogations from Articles 8 (respect for family and private life) and 10 (freedom of expression) ECHR are only permitted if, in accordance with the law and necessary in a democratic society in the interests of national security, public safety, or the economic well-being of the country, for the prevention of disorder or crime, for the protection of health or morals, or for the protection of the rights and freedoms of others.

87 In Von Hannover (Von Hannover v. Germany. App. no. 59320/00, judgment of 24.06.2004), the ECtHR, in assessing the publication of photos looked into five criteria: (1) whether the information contributes to a debate of general interest; (2) the notoriety of the person or people concerned; (3) the prior conduct of the person concerned; (4) the content, form, and consequences of the publication; (5) the circumstances in which the photos were taken.

${ }^{88}$ Para. 66: In particular, a data subject should have the right to have his or her personal data erased and no longer processed where the personal data are no longer necessary in relation to the purposes for which they are collected or otherwise processed, where a data subject has withdrawn his or her consent or objects to the processing of personal data concerning him or her, or where the processing of his or her personal data does not otherwise comply with this Regulation.

${ }^{89}$ G. Sartor, "The right to be forgotten: balancing interests in the flux of time", International Journal of Law and Information Technology, 2016, Vol. 24, p. 77.

90 Case C-398/18, Camera di Commercio,Industria, Artigianato e Agricoltura di Lecce v. Salvatore Manni, ECLI:EU:C:2017:197.

${ }_{91}$ Venditti v. Rai, 10583/2014, English summary available at: https://global freedomofexpression.columbia.edu/cases/venditti-v-rai/ (last accessed 14.02.2020).

${ }_{92}$ Directive 95/46/EC of the European Parliament and of the Council of 24 October 
was retained on the website of the Lecce Chamber of Commerce and subsequently processed by a company which specialized in the collection and processing of market information and in risk assessment. ${ }^{93}$ The lower tier Court awarded him damages, but this award was overturned by the appellate Court. The appellate Court referred several questions to the Court of Justice which essentially asked, "whether the directive on the protection of personal data and the directive on disclosure of company documents preclude any person from accessing, without any time limit, data relating to natural persons set out in the companies register." ${ }^{94}$ After establishing that the processing of personal data was legitimized under three lawful grounds ${ }^{95}$, and outlining the need, "to protect the interests of third parties in relation to joint stock companies and limited liability companies" as an objective of Directive 68/151, the Court found that in this case, Manni did not have a right to erasure. However did have a right to object to the processing. In its conclusion, the Court noted that the outcome might be different where the passage of time leads to the privacy rights of the individual outweighing the rights of third parties to find the information. ${ }^{96}$

1995 on the protection of individuals with regard to the processing of personal data and on the free movement of such data OJ L 281, 23.11.1995.

93 Case C-398/18, supra note 90, para. 24.

${ }^{94}$ Press Release, the referred to legislation are the data protection directive [Directive 95/46/EC] and the First Council Directive 68/151/EEC of 9 March 1968 on co-ordination of safeguards which, for the protection of the interests of members and others, are required by Member States of companies within the meaning of the second paragraph of Article 58 of the Treaty, with a view to making such safeguards equivalent throughout the Community (OJ 1968, L 65, p. 8), as amended by Directive 2003/58/EC of the European Parliament and of the Council of 15 July 2003.

95 Compliance with a legal obligation [Article 7(c)]; the exercise of official authority or the performance of a task carried out in the public interest [Article 7(e)] and the realization of a legitimate interest pursued by the controller or by the third parties to whom the data are disclosed [Article 7(f)].

96 Para. 60, when dealing with Art. 14 (a) of the 1995 Directive, "it cannot be excluded, however, that there may be specific situations in which the overriding and legitimate reasons relating to the specific case of the person concerned justify exceptionally that access to personal data entered in the register is limited, upon expiry of a sufficiently long period after the dissolution of the company in question, to third parties who can demonstrate a specific interest in their consultation". 
In Venditti v. Rai, the Italian public broadcaster Rai, aired a video of Venditti which was originally broadcast over five years ago. Venditti questioned the lawfulness of this broadcast on the ground of the right to erasure and the defamatory nature of the video. ${ }^{97}$ The lower tier Courts ruled against Venditti. The Supreme Court found that the case raised five issues, regarding Venditti's celebrity status, his right to be forgotten and the right of the public to be informed..$^{8}$ The Supreme Court found that the rebroadcast did not serve any public interest - it merely served the economic interests of the broadcaster. As the video was over five years old, Venditti's right to be forgotten weighed more than the public's right to be informed. The Court cited the judgment of Manni to emphasize this point. The rebroadcast also could not be deemed to be of a satirical nature. Despite captions being added to the video, the broadcast ultimately failed to place the video into context and potentially incorrectly portrayed Venditti. ${ }^{99}$

The element of time is emerging as a prominent component in the balancing of the Rtbf with competing rights, despite its not being listed in either the 1995 Directive, nor in the GDPR as a component to be taken into account. The Manni case first introduced this to the case law of the ECJ and both the German and Italian Supreme Courts have now included this in their balancing.

The element of time is far from being set in stone in the balancing process. In Rtbf 1 , the lower tier Court offered a solution from insolvency law which would see a deletion after six years. This idea was not approved by the appellate Court. Without the implementation of an alternative

97 Venditti v. Rai, supra note 91.

98 Specifically, 1) the benefit of the image or the news to the public debate; 2) the effectiveness of its dissemination at the current time, for example for reasons of justice, policy, or protection of rights or liberties of third parties, or for scientific, educational or cultural purposes, but not where the interest is merely economic; 3) whether the subject is well-known and especially when s/he is a public official; 4) the methods used to obtain the information/image which should be in accordance with responsible journalism and the ways in which it is disseminated which should not exceed the right to inform by being sensationalized or used to express personal opinions; 5) whether the subject was given prior notice and an opportunity to respond before publication, as summarized on https:/ / globalfreedomofexpression.columbia.edu/cases/venditti-v-rai/ (last accessed 14.02.2020).

99 Venditti v. Rai, supra note 91. 
expiration date for data, ${ }^{100}$ the Courts will need to find a way to harmonize how to account for the element of time. One such method could be the implementation of an internet balancing formula. ${ }^{101}$ Based on Alexy's weight formula ${ }^{102}$, it could provide a solution both for platforms and Courts to harmonize the balancing of the competing rights which come to play in the Rtbf. Furthermore, the solution could also be used by AI, which soon may be capable of conducting the balancing itself.

\section{Blockchain as the Next Battleground FOR THE RIGHT TO BE FORGOTTEN?}

Another issue facing the implementation of the Rtbf is the emergence of blockchain technology, which specifically functions through remembering all previous transactions. ${ }^{103}$

Blockchains are a form of distributed ledger technology, which are based on three technologies: public key cryptography; distributed peerto-peer networks; and consensus mechanisms. ${ }^{104}$ Blockchains can be permissionless (anyone can read the chain and write a new block into it) or permissioned (access to the blockchain must first be granted, therefore not truly decentralized). ${ }^{105}$

100 Mayer-Schönberger, supra note 4, p. 173.

101 M. Susi, “The Internet Balancing Formula”, European Law Journal, 2018, Vol. 25 (2), pp. 198 - 212 and further discussed in E. Marique, Y. Marique, "Sanctions on digital platforms: Balancing proportionality in a modern public square", Computer Law and Security Review, forthcoming 2019.

102 R. Alexy, A Theory of Legal Argumentation: The Theory of Rational Discourse as Theory of Legal Justification, Clarendon Press, 1989; and R. Alexy, A Theory of Constitutional Rights, Oxford University Press, 2002, passim.

${ }^{103}$ E. Dans, "Which makes more sense: blockchain or the "right" to be forgotten?", 2018, available at: https://medium.com/enrique-dans/which-makes-more-senseblockchain-or-the-right-to-be-forgotten-4a34e6762b59 (last accessed 13.12.2019).

104 M. Finck, "Blockchains and Data Protection in the European Union", European Data Protection Law Review, 2018, Vol. 1.

105 E. Politou, F. Casino, "Blockchain Mutability: Challenges and Proposed Solutions", IEEE Transactions on Emerging Topics in Computing, 2019, Vol. 99 (1). 
Currently, blocks contain pseudonymized transactional data, which has been deemed to constitute personal data under the GDPR. ${ }^{106}$ One of the key assets of blockchain technology is its 'immutability', i.e. the fact that it is nearly impossible to delete any data stored on the block. In fact, any changes to the chain would jeopardize the legitimacy of the entire blockchain. ${ }^{107}$ This, however, puts it at odds with the GDPR, specifically the right to revoke consent for processing under the Rtbf.

One possibility to resolve the conflict is for the blockchain to contain pointers only to the actual information, in which case the actual information would not be stored on the blockchain itself, opening the possibility of altering or deleting the information at a later stage. This solution, known as the off-storage option, would not amount to an actual erasure of the data, as the hash that remains in the blockchain may still allow for the identification of the individual involved in a transaction. ${ }^{108}$

Another possibility, known as perfect obfuscation is supposed to make it so difficult to decipher the hash that with current computing power, it would be impossible to read personal data out of it. ${ }^{109}$ The emergence of quantum computers is seen as a problem to this approach. ${ }^{110}$

A third approach could be the implementation of a 'chameleon hash', which would allow for a subsequent alteration of a block on the chain, while not changing the hash of the blocks stored afterwards. ${ }^{111}$ Similarly,

${ }^{106}$ Finck, supra note 104 - Public keys can reverse the anonymization, therefore Art. 4 (3) GDPR applies. They can also be tracked back to IP-addresses, which according to Patrick Breyer v. Germany, constitute personal data (C-582/14).

107 "If you purge a block of transactions, the truthfulness of all subsequent blocks of transactions becomes questionable." Transaction recording helps blockchains keep track of payments and a false transaction could have financial consequences for users. When it comes to the blockchain that Bitcoin is powered by, "all Bitcoin transactions after that purged block become untrustworthy, which would undermine the complete system," Van Humbeeck, in S. Liao, "Major blockchain group says Europe should exempt Bitcoin from new data privacy rule", 2018, https://www.theverge.com/2018/4/5/17199210/ blockchain-coin-center-gdpr-europe-bitcoin-data-privacy (last accessed 12.12.2019).

108 Finck, supra note 104, p. 24.

109 Ibid., p. 23.

110 Politou, Casino, supra note 105, p. 7.

111 Ibid., p. 8 - Chameleon hash allows for collisions. A "trapdoor key" allows for changes to that block. It has been argued that this turns the blockchain into a simple database and makes it vulnerable to attacks via the trapdoor. 
a memory flexible blockchain could change a hash so the content is lost, but verification that a transaction happened is retained. This could be combined with an expiration date for data retained on the blockchain. However, this would open an additional door for hackers by cutting the immutability of the blockchain. Furthermore, owing to the nature of each block referencing the hash of the previous one, the security of the chain increases the longer it gets. An expiration date would lead to an artificial shortening of the blockchain, which would come at the expense of security.

Some have argued that blockchain technology, as a novel technological development, should be subject to the exceptions listed in TFEU 101,112 or could already be under, "reasonable steps" compliance. ${ }^{113}$ On the other hand, Moerel and Storm argue that permissioned blockchains, which allow for the chameleon hash solution are already in compliance with the GDPR. The permissioned nature allows for a data controller to be identifiable (the administrator) and the chameleon hash allows for an effective implementation of the Rtbf. ${ }^{114}$

With the emergence of smart contracts, blockchain is starting to become more widely used in society. As the law does not provide clear guidelines regarding the compliance of distributed ledger technology with data protection laws, it will be up to the Courts to clarify if it is in compliance with the GDPR. Advocates of blockchain being in compliance

112 Finck, supra note 104, p. 33, Art. 101: 1. The following shall be prohibited as incompatible with the internal market: all agreements between undertakings, decisions by associations of undertakings and concerted practices which may affect trade between Member States and which have as their object or effect the prevention, restriction or distortion of competition within the internal market, and in particular those which: (...) (b) limit or control production, markets, technical development, or investment.

${ }_{113}$ GDPR Art. 17 (2): Where the controller has made the personal data public and is obliged pursuant to paragraph 1 to erase the personal data, the controller, taking account of available technology and the cost of implementation, shall take reasonable steps, including technical measures, to inform controllers which are processing the personal data that the data subject has requested the erasure by such controllers of any links to, or copy or replication of, those personal data.

${ }^{114}$ L. Moerel, M. Storm, "Why Blockchain is not inherently at odds with GDPR", 2019, available at: https:/ / mofotech.mofo.com/topics/why-blockchain-is-not-inherentlyat-odds.html (last accessed 14.02.2020). 
cite Manni ${ }^{115}$ and Sabam. ${ }^{116}$ The author predicts that similarly to the extraterritorial limitations established in CNIL and the importance of the element in time in Rtbf 1 and 2, Manni and Venditti, blockchain is likely to become one of the next fields in which the European Courts can shape policy and further develop the chain of law.

\section{CONCLUSION}

Through looking at current judgments of the European Courts regarding the Rtbf, this article has tried to provide evidence that Dworkin's theory on legal interpretivism is not an abstract theory which at best can only be applied to the US jurisdiction, but that there also is proof in the European context that judges may be acting in line with this school of thought. The lack of guidance on how to balance the Rtbf with competing rights and the emergence of new technologies not anticipated by the GDPR have opened paths for judges to actively shape the Rtbf.

Although the recent case-law does not widen the scope of the Rtbf, this does not rule out the possibility that future judgments may widen the scope of protection. The ongoing technological developments, balancing issues and the need for effective remedy against violations, are likely to lead to a call for clearer laws, not just in Europe, but globally. Ultimately, for an effective enforcement of the Rtbf, global solutions are required, at least if the internet is to still remain open and globally accessible. Judges will continue to play a vital role in this process.

115 Ibid. - in Manni the Court confirmed that the right to erasure is not absolute. Solutions which do not completely erase the data from the chain could be enough to accomplish the aim of Article 17, while taking into account the unique nature of blockchain.

${ }^{116}$ M. Schellekens, "Does regulation of illegal content need reconsideration in the light of blockchains?", International Journal of Law and Information Technology, 2019, Vol. 27, p. 302 - SABAM dealt with intellectual property infringements and determining who constitutes a data controller in a peer-to-peer network. It is argued that the lessons from SABAM can be applied to deduce a more flexible approach as to who constitutes a data controller in DLTs. 
